\title{
Evaluation of the removal of total phosphorus from sanitary effluent by Chlorella vulgaris in a small batch photobioreactor
}

Avaliação da remoção de fósforo total de efluente sanitário por Chlorella vulgaris em fotobiorreator de pequeno porte

\author{
J. C. Pereira*; A. I. L. F. Nascimento; Y. O. Carvalho; R. L. Pagano; C. F. Silva \\ Laboratório de Bioquímica Industrial / Programa de Pós-Graduação em Engenharia Química (PEQ), Universidade \\ Federal de Sergipe, CEP 49100-000, São Cristóvão-Sergipe, Brazil
}

*cabral.julianaa@gmail.com

(Recebido em 25 de julho de 2017; aceito em 23 de junho de 2018)

\begin{abstract}
The search of the scientific community for efficient and cheap technologies for the treatment of wastewater in Brazil continues being a challenge, mainly in the effort to encourage the government, responsible for the application and proliferation of these technologies. The release of contaminated effluent without treatment in the aquatic bodies leads to the degradation of these environments, what requires the reuse of these waters, facing environmental sustainability. In this context, microalgae establish a promising alternative, once the main attribute of algae culture in wastewater is its ability to efficiently assimilate organic carbon and inorganic nutrients from wastewater to achieve a clean effluent with efficient nutrient removal, besides a biomass production, accumulation of lipids, which can be converted into biodiesel. Assuming the important role of photosynthetic $\mathrm{CO}_{2}$ fixation, which helps to mitigate the alarming effects of the release of greenhouse gases into the atmosphere. The main objective of this work was to evaluate the capacity of the microalga Chlorela vulgaris in the removal of phosphorus from the sanitary sewage collected at the effluent treatment plant at Federal University of Sergipe using a small batch reactor. The results showed that the species Chlorella vulgaris were able to assimilate phosphorus and to remove organic matter (Chemical Oxygen Demand, COD) from the effluent. The results showed that photobioreactors using microalgae for the treatment of effluents is a promising technique and motivate additional studies, mainly due to their capability of adding value to the biomass generated during the treatment.

Keywords: microalgae, Chlorella vulgaris, wastewater treatment.
\end{abstract}

A busca da comunidade científica por tecnologias eficientes e de baixo custo para o tratamento de efluentes no Brasil continua sendo um desafio, principalmente no esforço de incentivar o governo, responsável pela aplicação e proliferação dessas tecnologias. A liberação de efluentes contaminados sem tratamento nos corpos aquáticos leva à degradação desses ambientes, o que exige o reuso dessas águas, frente à sustentabilidade ambiental. Neste contexto, microalgas estabelecem uma alternativa promissora, uma vez que o principal atributo da cultura de algas em águas residuais é a capacidade de assimilar carbono orgânico e nutrientes inorgânicos de efluentes para obter um efluente limpo com remoção eficiente de nutrientes, além de produção de biomassa e acúmulo de lipídios, que pode então ser convertido em biodiesel. Assumindo o importante papel da fixação fotossintética de $\mathrm{CO}_{2}$, que contribui para atenuar os efeitos alarmantes da liberação de gases de efeito estufa na atmosfera. O objetivo principal deste trabalho foi avaliar a capacidade da microalga Chlorella vulgaris na remoção do fósforo presente no esgoto sanitário coletado na estação de tratamento de efluentes da Universidade Federal de Sergipe utilizando um reator de pequeno porte. Os resultados mostraram que a Chlorella vulgaris utilizada foi capaz de assimilar o fósforo e remover a matéria orgânica (Demanda Química de Oxigênio, DQO) do efluente. Os resultados mostraram que o uso de fotobiorreatores utilizando microalgas para o tratamento de efluentes é uma técnica promissora e motivam estudos adicionais, principalmente devido à sua capacidade de agregar valor à biomassa gerada durante o tratamento.

Palavras-chave: microalgas, Chlorella vulgaris, tratamento de efluentes. 


\section{INTRODUCTION}

The undue release of untreated domestic effluent into lotic, and mainly lentic, lead to acceleration of eutrophication in many of these environments. Eutrophication is a process of environmental degradation resulting from increased concentration of nutrients in aquatic environments, mainly nitrogen $(\mathrm{N})$ and phosphorus $(\mathrm{P})$, leading to the proliferation of algae and other primary producers, whose growth and death increase the Biochemical Oxygen Demand (BOD), imposing anaerobic conditions and inadequate for the ecological health maintenance of the ecosystem, which can lead to the death of the lake [1].

Conventional plants used in wastewater treatment are effective in the removal of organic matter and suspended solids. However, their performance in removing nutrients $(\mathrm{N}$ and $\mathrm{P})$ at satisfactory levels is limited, unless advanced treatment methods are employed [2]. For instance, improved technology for removing nutrients would require an increase in energy consumption of about $60-80 \%$ [3].

Alternatively, removal of nitrogen and phosphorus can be accomplished chemically, such as precipitation using aluminum and iron salts. However, these methods require large quantities of chemicals and generate large amounts of contaminated sludge due to chemical reactions and precipitates [2]. To overcome these drawbacks, it is necessary to develop alternative methods for adjusting nutrient concentrations in effluents with lower energy demands, producing smaller amounts of waste and leading to cost reduction [3].

Another major issue to be addressed is that the greater the global demand for clean and potable water, the greater and more expensive are the technologies required to treat water collected from the environment. The main challenge of an effluent treatment plant is not only to produce reusable clean water, but also to seek for resources to endeavor growing pollutant loads, requiring everincreasing expenditures of chemicals and increasingly advanced technologies. According Cabanelas et al. (2013) [3], the global investment in water resources management were around 150 billion euros per year, of which $95 \%$ corresponds to public capital [3].

Microalgae are a satisfactory alternative in this scenario. The main attribute of algae culture in wastewater is its ability to efficiently assimilate organic carbon and inorganic nutrients from the waters, leading to biomass production, efficient nutrient removal and lipid accumulation, which can be converted into biodiesel [4]. Assuming the important role of photosynthetic, $\mathrm{CO}_{2}$ fixation, which helps to mitigate the alarming effects of releases of greenhouse gases into the atmosphere [5].

The great diversity of species of these photosynthetic microorganisms is already used for production of goods of high added value for health, such as pharmaceuticals, nutraceuticals, polysaccharides, betacarotenes, toxins, triglycerides, vitamins, pigments, besides biomass for human and animal food and biofuels [6].

One of the main field of research related to microalgae is the use of their biomass for energy production. The challenge in producing biofuels is the competition between farmland used to produce biofuel and food, which can affect food prices. The solution may be in the application of microalgae as a source of bioenergy [2]. The use of microalgae for the treatment of effluents adds two important functionalities, the proper treatment of effluents and the production of energy, besides the several other functionalities mentioned above [2].

Biodiesel, bioethanol and biohydrogen are products that can be produced from microalgae. It is well established that biofuels derived from microalgae have the potential to make a significant contribution to the fuel market. However, this is still not feasible due to the high costs, which can be significantly reduced by using domestic, agricultural and industrial effluents as a source of nutrients for the cultivation of microalgae [4].

Several technologies involving microalgae are being researched, including some that extrapolate the use of a single specific species with some success. Gonçalves et al. (2016) [7] studied a microalgae-bacteria consortium for tertiary effluent treatment, using Chlorella vulgaris, a microorganism widely used in effluent treatment processes due to its high nutrient removal capacity and the results showed that the consortium containing the bacteria $E$. asburiae e $R$. ornithinolytica significantly improved the growth of $C$. vulgaris. The time required to reach the 
effluent discharge limits (established by legislation) was reduced to half the values found for the culture of $C$. vulgaris alone.

Microalgae culture in effluents appears as a viable alternative for the reduction of nitrogen and phosphorus levels, since these microorganisms require high amounts of these nutrients for their growth. Microalgae develop naturally in wastewater, consume nutrients and have a rapid growth cycle (1 - 2 weeks) [7].

For the phosphorus, the mechanisms involved in its removal are bioassimilation, adsorption and chemical precipitation due to the increase of $\mathrm{pH}$ during the growth of the microalgae and the high concentration of dissolved oxygen [8].

The advantages of this treatment are (i) nitrogen and phosphorus assimilated by the microalga can be recycled to the production of microalgae biomass fertilizers; (ii) the resulting biomass can be used for bioenergy production; and (iii) an oxygenated effluent is discharged into the aquatic bodies [7]. In addition, microalgae can be harvested after treatment and used for production of biofuels or co-digested with sludge to increase biogas generation in treatment plants [8].

The treatment of effluents using microalgae, in association or not with activated sludge, would lead to increased treatment plant revenues, green energy production, and the reduction of carbon dioxide emissions to the atmosphere [8].

Amini et al. (2016) [4] studied the influence of environmental conditions on the growth rate of microalgae and proposed a model to describe this behavior. They observed that the depth of the medium is a very important factor for the growth rate, as well as the luminous intensity. The objective of this work was to know the influence of environmental factors to optimize the production of biomass from microalgae, providing the production of biofuels from these microorganisms.

The main objective of this work was to evaluate the ability of Chlorella vulgaris microalgae to remove the phosphorus present in sanitary effluent from the effluent treatment plant of the Federal University of Sergipe using a batch reactor, as well as to compare the behavior of microalgae in synthetic effluent.

\section{MATERIALS AND METHODS}

\subsection{Chlorella vulgaris strain}

The strain of the microalga Chlorella vulgaris used in this study was supplied by the Algae Biotechnology Laboratory at Botany Department at Federal University of São Carlos in São Paulo, Brazil. The maintenance of the microalgae was carried out in WC medium properly sterilized, proposed by Guillard and Lorezen (1972) [9].

\subsection{Inoculum}

The inoculum of the pure effluent and the effluent diluted to $50 \%$ were prepared from the mixture of two solutions. Solution A composed of $250 \mathrm{~mL}$ of effluent diluted to $20 \%$ and solution B composed of $250 \mathrm{~mL}$ of effluent diluted to $40 \%$. Both solution A and B contained $10 \%$ by volume of an aliquot stock of microalgae in the Laboratory of Industrial Biochemistry of UFS.

\subsection{Effluents}

Synthetic effluent was prepared from $2.5 \mathrm{~L}$ of WC medium, two-fold more concentrated, by adding $250 \mathrm{mg}$ of monopotassium phosphate $\left(\mathrm{K}_{2} \mathrm{HPO}_{4}\right)$ and $250 \mathrm{mg}$ of sodium nitrate $\left(\mathrm{NaNO}_{3}\right)$. The $\mathrm{pH}$ of the effluent was adjusted to approximately 7.5 , followed by sterilization in autoclave. After to cool down, the inoculum was added.

Sanitary effluent samples were collected at the treatment plant, at the outlet of the upflow anaerobic sludge blanket reactor (UASB). This effluent was used pure or diluted by mixing 1.25 $\mathrm{L}$ of effluent with $1.25 \mathrm{~L}$ of distilled water. Then the medium was inoculated in the ratio of 250 $\mathrm{mL}$ of inoculum to $2.5 \mathrm{~L}$ of effluent.

\subsection{Effluent treatment}

The samples of synthetic effluent and the sanitary effluent diluted and pure, were treated with the microalgae for 21 days in 24 hours of photoperiod, in glass flasks of $3 \mathrm{~L}$ each. This treatment 
was performed under incubation conditions using artificial illumination through a $25 \mathrm{~W}$ and 60 $\mathrm{Hz}$ lamp and with continuous stirring through an air nebulizer with a mist rate of $0.4 \mathrm{~mL} / \mathrm{min}$ and $50 \mathrm{psi}$ of pressure. Aliquots for analysis of biomass growth and phosphate concentration were withdrawn every 3 days.

\subsection{Analysis}

The biomass content analysis was performed by measuring treated samples absorbance in a spectrophotometer (Biospectro, SP-220) at the wavelength of $570 \mathrm{~nm}$.

A standard curve of dry biomass was constructed. From this curve the following Equation 1.

$$
\mathrm{Y}=27.463 * \mathrm{X}
$$

Where $\mathrm{Y}$ is the absorbance and $\mathrm{X}$ is the concentration. To obtain the concentrations related to the absorbances in this work, substitute the $\mathrm{Y}$ of the equation for the absorbance obtained in each analysis, obtaining the respective concentration of the samples.

Total phosphorus content was measured according to the Standard Methods for the Examination of Water and Wastewater [15]. Initially, a $5 \mathrm{~mL}$ aliquot of each sample was taken, acidified and heated to $100^{\circ} \mathrm{C}$ for 1 hour to promote sample digestion. After cooling, the sample was neutralized with 1 mol.L $\mathrm{L}^{-1}$ sodium hydroxide solution by using phenolphthalein as colorimetric indicator. Five milliliters of the neutralized sample were taken and $1.6 \mathrm{~mL}$ of a color developing solution was added, lasting for 4 hours to stabilize its color. The standard solutions of phosphorus used to plot the calibration curve were made from a stock solution obtained by dissolving $0.02195 \mathrm{~g}$ of anhydrous monopotassium phosphate $\left(\mathrm{KH}_{2} \mathrm{PO}_{4}\right)$ in distilled water and completing the volume to $500 \mathrm{~mL}$ in a volumetric flask. This stock solution has the concentration of $10 \mathrm{mg} / \mathrm{L}$ phosphate $\left(\mathrm{P}_{-} \mathrm{PO}_{4}{ }^{3-} \cdot \mathrm{L}^{-1}\right)$. Both the samples and the calibration curve were analyzed in relation to their absorbance at the wavelength of 880 nanometers.

The Chemical Oxygen Demand (COD) analyses were performed using the open COD reflux titration methodology according to the Standard Methods for the Examination of Water and Wastewater [15], by mixing $5 \mathrm{~mL}$ of sample, $10 \mathrm{~mL}$ of dichromate solution, $15 \mathrm{~mL}$ of sulfuric $\mathrm{acid} / \mathrm{silver}$ sulfate solution (prepared by adding $10 \mathrm{~g}$ of silver sulfate to $1000 \mathrm{ml}$ of concentrated sulfuric acid) were added. The sample was then digested for 2 hours under heating. After digestion, $50 \mathrm{~mL}$ of distilled water were added and the resulting solution was titrated against 0.25 mol. $\mathrm{L}^{-1}$ ammoniacal ferrous sulfate, using ferro in as indicator.

\section{RESULTS AND DISCUSSION}

The growth evaluation of the microalga Chlorella vulgaris using a photobioreactor in three different culture media is depicted in Figure 1. The evaluation of the growth of $C$. vulgaris microalgae using a photobioreactor in three different culture media is described in Figure 1. The aim of the aeration was to promote the homogenization of the medium, facilitating the contact of the microalgae with the nutrients.

It can be seen from Figure 1 that the growth kinetics of $C$. vulgaris in nature sanitary effluent is consistent. The two samples prepared (from pure or diluted) effluent showed lower biomass growth than that observed for the synthetic medium, during the observed period. This can be explained by the higher concentration of nutrients present in the synthetic medium, and the higher turbidity of the nature effluent, since according Amini et al. (2016) [4] the efficient growth of microalgae depends on environmental variables and the concentrations of essential nutrients such as $\mathrm{N}$ and $\mathrm{P}$, the optimal temperature, light intensity and $\mathrm{pH}$ for maximum algal growth rate vary among algal. After the $17^{\text {th }}$ day, it is possible to observe a decrease of growth in the diluted medium $(50 \%)$ due to the agglomeration of microalgae cells. 


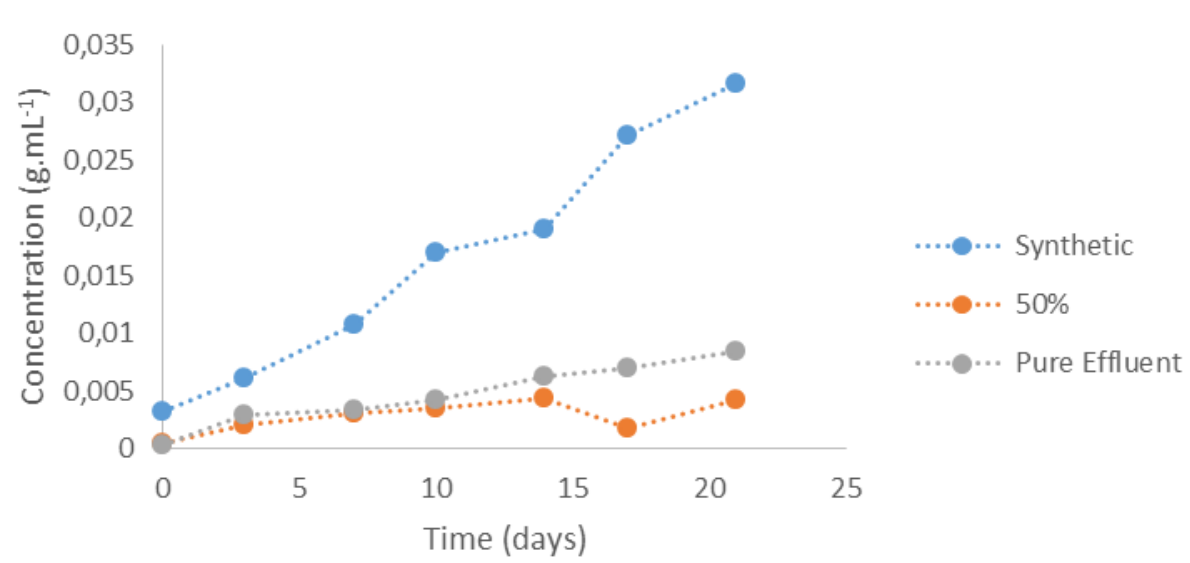

Figure 1 - Concentration of the biomass produced by the microalga Chlorella vulgaris as a function of the cultivation time in Synthetic Effluent, Sanitary Effluent Diluted and Sanitary Effluent Pure.

The effluent samples were collected after secondary treatment to provide suspended solids removal and to get the population of species that could compete with microalgae for light and nutrients, as suggested by Ramos et al. (2013) [10].

The results of phosphate removal can be seen in Table 1. The results show that the growth of microalgae and the removal of phosphorus are related processes, since the increase of the biomass content coincided with the decrease of the total phosphorus content.

Table 1: Removal of phosphate in culture media used

\begin{tabular}{cccc}
\hline & \multicolumn{2}{c}{ Phosphorus Concentration } & \\
\cline { 2 - 4 } Medium & Initial (g/mL) & Final (g/mL) & \% Removal \\
\hline Synthetic Effluent & 50.08 & 5.12 & 89.78 \\
Sanitary Effluent & 13.47 & 6.43 & 49.44 \\
Diluted (50\%) & & & 75.82 \\
Sanitary Effluent & 26.94 & 6.51 & \\
Pure (100\%) & & &
\end{tabular}

The removal of the total phosphorus content in the sanitary effluent was approximately $75 \%$, which is a very acceptable rate and shows the viability of the use of this microalga in the removal of phosphorus in the wastewater treatment plants. Almomani et al. (2016) [8] reported that a mixed indigenous microalga showed phosphorus removal efficiencies of $79 \%$, and $49 \%$ in primary effluent and secondary effluent, respectively. Higher phosphorus removal was obtained for $C$. vulgaris in the study performed by Gonçalves et al. (2016) [7]: when growing C. vulgaris in synthetic media and different consortia of microalgae, phosphorus removal ranged from 95.6 \pm 2.2 to $96.2 \pm 1.4 \%$.

Regarding the way in which nutrient removal occurs, associated to the growth of microalgal biomass, Posadas et al. (2013) [11] suggests that carbon and nitrogen are removed by biomass assimilation and exhaustion. Already the phosphorus removed by biomass assimilation and exhaustion. Already the phosphorus removal is mainly due to assimilation into biomass and precipitation at high $\mathrm{pHs}$. Its removal is mainly due to assimilation and occurs concomitantly with the reduction of the concentration of other nutrients [10].

Chemical Oxygen Demand (COD) is an important parameter in the control of effluent treatment. This parameter measures the amount of organic matter susceptible to oxidation under the conditions of COD tests. Table 2 shows the results for COD in all media studied for samples collected at the beginning and at the end of the treatment of the effluents with the microalga. 
Table 2: Removal analysis of chemical oxygen demand in the effluent.

\begin{tabular}{|c|c|c|c|}
\hline \multirow[b]{2}{*}{ Medium } & \multicolumn{2}{|c|}{$\mathrm{COD}(\mathrm{mg} \mathrm{O} / \mathrm{L})$} & \multirow[b]{2}{*}{ \%Removal } \\
\hline & Initial $(\mathrm{g} / \mathrm{mL})$ & Final $(\mathrm{g} / \mathrm{mL})$ & \\
\hline Synthetic Effluent & 360 & 80 & 77.78 \\
\hline $\begin{array}{l}\text { Sanitary Effluent } \\
\text { Diluted }(50 \%)\end{array}$ & 480 & 160 & 66.67 \\
\hline $\begin{array}{l}\text { Sanitary Effluent } \\
\text { Pure }(100 \%)\end{array}$ & 480 & 200 & 58.33 \\
\hline
\end{tabular}

The results show the efficiency of the microalga in the elimination of organic compounds, expressed in terms of COD removal, which was $58.33 \%$ for the sanitary effluent pure. The reductions of COD in the sanitary effluent, either pure or diluted, were very similar. Rodrigues and Belli Filho (2004) [12], also obtained a satisfactory result, in which the COD reduction varied between 96 and 86\%. For secondary effluent, Almomani et al. (2016) [8] reported a COD removal were $49.1 \%$

Posadas et al. (2014) [11] describe that to adapt this process to its use in a real effluent treatment plant, the period of maximum removal of nutrients and organic matter must be determined, since the depletion of the carbon source in the form of $\mathrm{CO}_{2}$ is precisely the cause for limiting microalgae productivity.

\section{CONCLUSION}

The tertiary treatment of effluents using the microalgae Chlorella vulgaris is very efficient, since it showed a significant reduction in total phosphorus and COD contents, attaining, respectively $75.82 \%$ and $58.33 \%$ of removal for the sanitary effluent pure. The higher the concentration of nutrients, the faster will be the growth of microalgae and the more efficient will be the removal of phosphate. Synthetic effluent containing higher phosphate loading exhibited greater microalgae growth rates and a phosphate reduction of $86.6 \%$, which was $34.3 \%$ greater than the value attained by diluted effluent and $11 \%$ higher than that one for pure effluent.

The results obtained for the tests with sanitary effluent pure showed the use of microalgae as tertiary treatment is feasible, reducing nutrients and organic load, providing the effluent disposal according to the Brazilian standards. The combination of photobioremediation of waste water and with carbon dioxide capture by algae and the production of biofuels from the yielded biomass is very promising and motivate the continuation of the study.

\section{ACKNOWLEDGMENTS}

The authors thank the Federal University of Sergipe for technical support and infrastructure to carry out this work and the Federal University of São Carlos for the strain of the microalga $C$. vulgaris.

\section{REFERENCES}

1. Mota FSB, Von Sperling M. (Coordenadores) Nutrientes de esgoto sanitário: utilização e remoção. $1^{a}$ Edição. Projeto PROSAB. Rio de Janeiro: ABES; 2009. 428p.

2. Abdullah MA, Ahmad A, Shah SMU, Shanab SMM., Ahmed AHE, Abo-State MAM, Othman MF. Integrated algal engineering for bioenergy generation, effluent remediation, and production of highvalue bioactive compounds. Biotechnol Bioprocess Eng. 2016;21:236-249; doi:10.1007/s12257-015$0388-2$

3. Cabanelas ITD, Arbib JRZ, Chinalia FA, Garrido-Pérez C, Rogalla F, Nascimento IA, Perales JA. Comparing the use of different domestic wastewasters for couplinh microalgal production and nutrient removal. Bioresource Thechnol. 2013;131:429-436, doi:10.1016/j.biortech.2012.12.152

4. Amini H, Wang L, Shahbazi A. Effects of harvesting cell density, medium depth and environmental factores on biomass and lipid productivities of Chlorella vulgaris grown in swine wastewater. Chemical Eng Science. 2016;152:403-412, doi:10.1016/j.ces.2016.06.025 
5. Michał A, Janusz L, Agnieszka S. $\mathrm{CO}_{2}$ Biofixation and Growth Kinetics of Chlorella vulgaris and Nannochloropsis gaditana. Appl Biochem Biotechnol. 2016;179:1248-1261, doi:10.1007/s12010-0162062-3

6. Abou-Shanab REDA, El-Dalatony MM, El-Sheekh MM, Ji M, Salama E, Kabra AN, Jeon B. Cultivation of a new microalga, Micractinium reisseri, in municipal wastewater for nutrient removal, biomass, lipid, and fatty acid production. Biotechnol Bioprocess Eng. 2014;19:510-518, doi:10.1007/s12257-013-0485-z

7. Gonçalves AL, Pires JCM, Simões M. Wastewater polishing by consortia of Chlorella vulgaris and activated sludge native bacteria. J Cleaner Production. 2016;133:348-357, doi:10.1016/j.jclepro.2016.05.109

8. Almomani FA, Örmeci B. Performance of Chlorella vulgaris, Neochloris oleoabundans, and mixed indigenous microalgae for treatment of primary effluent, secondary effluent and centrate. Ecol Eng. 2016;95:280-289, doi:10.1016/j.ecoleng.2016.06.038

9. Guillard RRL, Lorenzen CJ. Yellow green algae with chlorophyllid-c. J Phycol. 1972;8:10-14.

10. Ramos Tercero EA, Sforza E, Morandini M, Bertucco A. Cultivation of Chlorella protothecoides with a urban wastewater in continuous photobireactor: Biomass productivity and nutrient removal. Applied Bioch Biotechnol. 2013 Nov;172:1470-1485, doi:10.1007/s12010-013-0629-9.

11. Posadas E, Muñoz A, García-Gonzalez M, Muñoz, R, Encina PAG. A case study of a pilot high rate algal pond for treatment of fish farm and domestic wastewaters. Journal of Chemical Technology and Biotechnology. 2014 Mai;90:1094-1101, doi:10.1002/jctb.4417

12. Rodrigues JBR, Belli Filho P. Eficiência da microalga Chlorella minutissima no tratamento de resíduos de suinocultura enriquecido com uréia. Rev Biotemas. 2004;17(2):7-26.

13. Sperling, M. Introdução a qualidade das águas e ao tratamento de esgotos. 2. ed. rev. Belo Horizonte, MG: Departamento de Engenharia Sanitaria e Ambiental - DESA; 1996. 243 p.

14. Pérez-Hernandez A, Labbé JI. Microalgas, cultivo y benefícios. Rev Biol Marinha Ocean. 2014 Ago;49(2):157-173, doi:10.4067/S0718-19572014000200001

15. Rice EW, Baird RB, Eaton AD, Clescerl LS. Standard methods for the examination of water and wastewater, 22th ed. American Public Health Association, Washington, DC; 2012. 